\title{
Bioecological characteristics and importance of feed in xerophy ts in the memorial desert plant of the Caspian coast
}

\section{Humira Z. Huseynova}

Baku State University, Baku, Republic of Azerbaijan, humire83@mail.ru

Abstract. In order to effectively use the natural ecosystem, the phytocenological structure of the region's vegetation was studied by conducting geobotanical research on the Caspian coast (in the territory of the Republic of Azerbaijan). Taxonomy and ecological-geobotanical map have been compiled. Morphological and ecological features of the species dominating the desert and semi-desert plant groups of the area were studied, as well as their phytocenological classification was developed at the level of type, formation and associations. The modern phytocenological classification of the studied vegetation not only protects the biodiversity of the area, but also provides a basis for its efficient use and protection. Taking into account the relief of the area and the diversity of soil and climatic conditions, it was determined by the phytocenological classification of vegetation that phytocenoses belonging to semi-desert, halophytic and psammophytic desert types are widespread in the vegetation of the Caspian coast. A new classification of Caspian coastal vegetation has been prepared with reference to our research and studies. According to this guideline and methodology, the classification of desert and semi-desert vegetation is based on eco-phytocenological principles, provided that the life forms of dominant and subdominant species, as well as the systematic taxonomic formations are named according to species and genera, as reflected in the descriptions recorded during field research. Thus, based on our geobotanical research and chamber studies, the modern classification of vegetation of the Caspian coast revealed that the plant species belonging to xerophytes in the natural phytocenoses of the area are Chenopodiaceae Vent., Asteraceae Dumort. and Poaceae Barnhart. are represented in the chapter.

Keywords: vegetation, formation, association, xerophytes, edificator, dominant, subdominant.

For citation: Huseynova H. Z. Bioecological characteristics and importance of feed in xerophyts in the memorial desert plant of the Caspian coast. Agrarnyy nauchnyy zhurnal = Agrarian Scientific Journal. 2021;(10): 18-21 (In Russ.). http://dx.doi.org/10.28983/asj.y2021i10pp18-21.

Аграрный научный журнал. 2021. № 10. С. 18-21

Agrarian Scientific Journal. 2021;(10): 18-21

Научная статья

\section{АГРОНОМИЯ}

УДК 581

doi:10.28983/asj.y2021i10pp18-21

\section{Биоэкологические характеристики и важность питания ксерофитов в мемориальном пустынном растении Каспийского побережья}

\section{Хумира Зафар Гусейнова}

Бакинский государственный университет, Баку, Республика Азербайджан, humire83@mail.ru

Аннотащия. В целях эффективного использования природной экосистемы была изучена фитоценологическая структура растительности региона путем проведения геоботанических исследований на побережье Каспийского моря (на территории Азербайджанской Республики). Составлена таксономия и эколого-геоботаническая карта. Были изучены морфологические и экологические особенности видов, доминирующих в пустынных и полупустынных группах растений района, а также разработана их фитоценологическая классификация на уровне типа, формирования и ассоциаций. Современная фитоценологическая классификация изучаемой растительности не только защищает биоразнообразие района, но и обеспечивает основу для его эффективного использования и защиты. Учитывая рельеф местности и разнообразие почвенно-климатических условий, фитоценологической классификацией растительности было определено, что в растительности Каспийского побережья широко распространены фитоценозы, относящиеся к полупустынному, галофитному и псаммофитному типам пустынь. На основе наших и других исследований была подготовлена новая классификация прибрежной растительности Каспия. В соответствии с этим руководством и методологией классификация пустынной и полупустынной растительности основана на эколого-фитоценологических принципах при условии, что формы жизни доминирующих и субдоминантных видов, а также систематические таксономические образования названы в соответствии с видами и родами, как отражено в описаниях, зарегистрированных в ходе полевых исследований. На основе наших геоботанических исследований и камерных исследований современная классификация растительности Каспийского побережья показала, что видами растений, относящимися к ксерофитам в естественных фитоценозах района, являются Chenopodiaceae Vent., Asteraceae Dumort. и Поасее Барнхарт.

Ключевые слова: растительность, формирование, ассоциация, ксерофиты, эдификатор, доминанта, субдоминант.

для циттирования: Гусейнова Х. З. Биоэкологические характеристики и важность питания ксерофитов в мемориальном пустынном растении Каспийского побережья // Аграрный научный журнал. 2021. № 10. C. 18-21. http://dx.doi.org/10.28983/asj.y2021i10pp18-21.

Introduction. In modern times, the protection of the environment and the efficient use of natural forage areas, the prevention of ecological imbalances and degradation in the biogeocenosis as a result of the negative effects of anthropogenic factors on soil and vegetation are urgent. From this point of view, geobotanical researches of winter pastures located in the Caspian coast of Azerbaijan (northern, middle and southern parts), as well as peri-rural pastures were carried out taking into account the bioecological features and forage importance of xerophytes in semi-desert vegetation $[14,2,3,8]$. In addition, the bioecological features of edificatory xerophytes specific to the main formations of semi-desert vegetation have been studied on a scientific and methodological basis $[7,4,6,10]$.

Research methods and objects. Herbariums collected from semi-desert phytose-noses growing in the Caspian coastal area in 2016-2019 were systematically taxed on xerophytes $[12,5,16]$. In particular, the ecological analysis of xerophytes is given $[11,13,8]$. 
Plant species belonging to xerophytes have been identified Chenopodiaceae Vent., Asteraceae Dumort. and Poaceae Barnhart. are represented in the chapter.

Of the 1,054 species found in the wild flora of the Caspian coast, xerofits account for 199 species, or $18.9 \%$. Studies show that xerophytes in the flora of the Caspian coast belong to the following groups: 1) Xerohalophytes - 4 species $(0.4 \%) ; 2)$ haloxerophytes -10 species $(0.9 \%)$; 3 ) psammoxerophytes - 78 species $(7.4 \%)$; 4 ) mesoxerophytes 197 species $(18.7 \%)$.

Xerophytes are plants that are permanently or gradually dehydrated, spread in arid areas and are found in a wide range of semi-deserts and deserts $[8,7,11,9]$. In this sense, xerophytes are formed in a dry arid habitat $[2,6,10]$.

It should be added that among the semi-desert plants of arid regions of Azerbaijan, species belonging to ephemerals and ephemeroids are characteristic of xerophytes [12, 9, 8, 4].

As a result of ecological-geobotanical researches in the semi-desert vegetation of the northern, middle and southern parts of the Caspian coast, xerophytic plants of selected formation groups were identified as research objects in Samur-Shabran lowland, Absheron peninsula and South-Eastern Shirvan plain [7, 10].

The semi-desert vegetation is spread on a low slope, starting from the shores of the Caspian Sea at an altitude of 28 to 200 meters above sea level. Here, these phytocenoses are spread on gray, gray-meadow, meadow-gray and graybrown soils [3].

The average annual temperature in the area is $14.50 \mathrm{C}$, the amount of precipitation does not exceed $240-300 \mathrm{~mm}$; $75-80 \%$ of it falls in spring, autumn and winter, and xerophytes are edificatory due to the relative increase in humidity in the semi-deserts [7, 9].

As a result of research, the presence of plant formations characterized by major xerophytes in the semi-desert phytocenoses of the Caspian coast was revealed. Therefore, the classification of semi-desert vegetation of the area was first developed by us in accordance with the "Map of natural vegetation". The classification of vegetation is based on ecological-phytocenological features and the principle of dominance in 7 groups of formations (reflected in contour numbers 23, 24, 25, 26, 27, 28, 29).

\section{Classification scheme of semi-desert vegetation}

\section{Type-Semi dessert}

Formation groups - Artemisieta; Artemisietum-Ephemerosum; Ephemereta-Salsoletum-Artemisiosum; EphemeretaPetrosimonietum-Artemisiosum; Petrosimonieta-Salsoletum-Artemisiosum; Salsoletum-Artemisiosum; Salsoletum-Artemisiosum.

Below are the bioecological features of edifice xerophyte species and the importance of forage on the formations of semi-desert vegetation distributed on the Caspian coast.

Vegetation of the Artemisietum lerchiana association of the Artemisietum formation is found in the Samur-Shabran lowland in the northern part of the Caspian coast - Siyazan region and in the south of the Caspian coast - in the winter pastures of Neftchala region [7, 10]. The edificator and dominant species of this formation in the species composition is Artemisia lerchiana Web. perennial herb by life form, $20-40 \mathrm{~cm}$ tall; hairy at the beginning of vegetation, then hairless, solitary and branched in the middle. The leaves are twice as thin and linear as feathers. Propagated by seeds. It flowers in September-October and sows in November-December.

Fragrant wormwood is a pasture plant with a high forage value, widespread in the winter pastures of Neftchala region, as well as in the pastures of the village of Neftchala, with the lands of Zarat municipality of Siyazan region to the Samur-Absheron canal. In particular, the insurance of these types of pastures constitutes a fodder reserve.

In the semi-desert plant, fragrant wormwood-ephemeral, ephemeral-blackberry-wormwood, ephemeral-winterwormwood, winter-blackberry-wormwood, blackberry-wormwood and blackberry-wormwood-wormwood formations were formed. It is considered a "masterpiece" or edificator of winter pastures. Aromatic wormwood is not eaten at all by small horned cattle in early spring and summer; eaten well in late autumn and winter. The wormwood plant is found in conjunction with ephemeral and ephemeroids, as well as ephemeral and ephemeroids in the snow cover. It is a good fodder for sheep [6]. Phytosenosis of Artemisietum-Ephemerosum formation in Yeni Yashma administrative-territorial district of Shabran, Siyazan and Khizi regions, with the lands of Shurabad municipality up to Samur-Absheron canal, as well as in the winter pastures of Absheron region. -formed on gray type soils. Artemisia lerchiana, which is considered an edificator of this formation, is a subdominant. The species includes xerophytic ephemerals with short growing season - Bromus japonicus, Lolium rigidum, Hordeum leperinum, Medicago minima, etc., as well as Poa bulbosa and others. ephemeroids are involved. Here, ephemerals and ephemeroids begin to vegetate after the first autumn rains, their growth accelerates with increasing temperature in early spring, forming a whole green cover (sinusoidal), flowering and seeding are destroyed in a short time $[4,7,9]$. Therefore, we give brief information about the bioecological features of ephemeral and ephemeroid plants (mentioned earlier) and the importance of feed.

Bromus japonicus Thunb. Belongs to the family Poaceae and is an ephemeral shield up to $15-35 \mathrm{~cm}$ in height. The roots are thinly fringed; trunks are branched in the rock. The leaves are linear. It flowers in May and bears seeds in June-July. It is found in groups of all xerophytic species formed by fragrant wormwood [4, 7]. Smallhorned cattle eat plants well until they produce seeds; After flowering, it quickly sows, dries and sheds spikes. Has a medium quality feed value. It is advisable to use Japanese bonfires in the creation of cultural pastures. Lolium rigidum Gaidin is ephemeral. Propagated by seeds. The trunks are $10-25 \mathrm{~cm}$ high. The leaves are flat. The spike is

(сГусейнова Х. 3., 2021 
thin, straight or slightly bent. It flowers in April-May and bears seeds in May-June. Solid wormwood and fragrant wormwood were dominant and subdominant in the species composition of the wormwood-ephemeral formation; It is a good fodder plant for pastures and pastures. It is well eaten by small horned cattle or cattle at the beginning of the growing season, as well as during flowering and seeding. Its seeds can be sown in early spring in sparse phytocenoses formed by fragrant wormwood, as well as pure ephemeral, to increase the productivity of pastures and pastures [7, 3].

Hordeum leporinum Link. - ephemeral. It is $15-20 \mathrm{~cm}$ high. The spikes consist of dense spikes and are $4-5 \mathrm{~cm}$ long. The bristles are stiff. It flowers and bears seeds from April to June. It is widespread in the species composition of semidesert plant formations. Until flowering, it is eagerly eaten by cattle, then rough and almost inedible. Its hard bristles stick to the wool of sheep and reduce the quality of the wool, sometimes piercing the skin of cattle. Therefore, it is not recommended to graze sheep in the most common areas until seeding $[4,7]$.

Medicago minima L. Bartalim, belonging to the family Fabaceae, is ephemeral. It is $5-10 \mathrm{~cm}$ high and its beans are covered with 3-5 curved thorns. Propagated by seeds. In the ephemeral sinus of formations in wormwoodephemeral and other semi-desert plants, Little Blackthorn is found in a sparse area. Beans are well eaten by cattle until the ripening stage. During the ripening period, the thorny beans stick to the sheep's wool and litter it. Therefore, in winter pastures, it is necessary to use Little Blackberry as a fodder plant during the budding and flowering phase.

Poa bulbosa is a perennial herb belonging to the ephemeroids. It is a pasture plant that forms a small lawn. Propagated by bulbs and seeds. Onions in the roots are round. The trunks are $10-40 \mathrm{~cm}$ high and the broom is dense. Some of the seeds germinate on the spike, the bulbs turn into tubers and fall to the ground and germinate in the soil. It is the most important pasture and pasture plant. It is well eaten by small cattle. In autumn, like other ephemeral plants, the surface gives a green mass, in winter the growth is somewhat weakened; It begins a strong vegetation in early spring, blooms in April-May, produces seeds and dries out the surface mass.

Vegetation of the Ephemereta-Salsoletum-Artemisiosum formation is found in the Shabran and Khizir regions in the northern part of the Caspian coast. The dominant of this formation is Artemisia lerchiana Web., The subdominants are Salsola dendroides Pall., As well as ephemerals - Bromus japanicus, Lolium rigidum, Eremopyrum orientale (L.) Jaub et Spach. and so on. are considered xerophytic species. It is represented by the phytocenosisEphemereta-Salsoletum dendroides-Artemisiosum lerchiana association. Salsola dendroides Pall. - is a semicircle. Haloxerophyte plant with a woody trunk, $40-60 \mathrm{~cm}$ tall. Its trunk is multi-branched, the leaves are round, elongated, soft and brittle. It germinates in April-May, flowers in October and sows in November. Sheep eat blackberries well in winter. Ephemereta - Petrosimonietum - Artemisiosum is registered in saline meadow-gray soils. Dominant of the formation - Artemisia lerchiana Web., Subdominant Petrosimonia brachiata (Pall.) Bunge., As well as Eremopyrum orientale (L.) Jaub. et Spach., Anisantha rubens (L.) devski et al. xerophyte is considered ephemeral. Therefore, we provide information on the bioecological characteristics of branched winter grass and the importance of feed.

Petrosimonia brachiata (Pall.) Bunge. - unity is grass; It is 10-20 cm tall, woolly, with scattered branches, hairy, and then hairless. The leaves are semi-cylindrical, facing each other. It flowers in April-May and the seeds ripen in October. The plant participates in the third floor or tier of the corresponding vegetation formation in saline, meadow-gray and saline soils in the Caspian winter pastures. Branches are not eaten by small cattle at the beginning of the growing season. However, after the germination phase of the vegetation, after the effects of winter frosts, the herds eat it enough. In this phytocenosis it is found in dry saline soils with P. Brachiata subdominance. The formation of pure forests of the plant is associated with pasture degradation [9]. Research shows that Petrosimonia brachiate (Pall.) Is an indicator of saline soils $[7,10]$. The Petrosimonieta-Salsoletum-Artemisiosum formation was recorded in the Shabran and Khizi districts, as well as in the saline meadow-gray soils between the Samur-Absheron canal and the Sumgayitchay administrative-territorial district. The vegetation of this formation is spread at an altitude of 28 to 35 meters above sea level. The dominant phytocenosis is Artemisia lerchiana, and the subdominants are Salsola dendroides and Petrosimonia brachiate. Information on the bioecological characteristics and feed quality of these xerophytic species is disclosed in previous formations.

The Salsoletum-Artemisiosum formation is represented by the Salsoletum dendroides-Artemisiosum lerchiana association. It is mainly distributed in the Caspian coastal lowland between the lands of the Yashma administrative-territorial district and the saline gray-brown soil between the Samur-Absheron canal, as well as in a wide area (meadow-gray soil) within the Shirvan National Park. The vegetation of the formation is of great forage importance [7].

The formation of Salsoletum-Artemisiosum was noted in the association Salsoleta den $\neg$ droides - Salsoletum dendroides - Artemisiosum lerchiana.

Vegetation of this formation is mainly found in a wider area than other phytose-noses recorded in the semi-desert. In particular, the plant grouping is found in the pastures of Shurabad municipality through the Samur-Absheron canal passing through the territory of Khizi region.

At the same time, the relevant formation was recorded in the low slope to the border of Gobustan reserve, as well as in the salty gray-meadow soils with the main Shirvan collector in the territory of Salyan region.

The dominant form of the formation is Artemisia lerchiana Web., Subdominants Salsola nodulosa (Mog.) Iljin.) And Salsola dendroides Pall. are considered [7, 10]. 
Result.Below is Salsola nodulosa (Mog.) Iljin. bioecological features and the importance of feed are described.

Salsola nodulosa (Mog.) Iljin. - according to the form of life. It has a scattered branching, light-gray bark body and is $30-45 \mathrm{~cm}$ high. Young shoots are small and hairy. The leaves are arranged alternately on the branches, up to $5 \mathrm{~mm}$ long. Propagated by seeds. Vegetation begins in June-July, blooms in July-August and seeds ripen in September-November. It is distributed in meadow-gray and saline soils from plains and small hills to slopes [9, 7].

This species is one of the main forage crops of winter pastures. Plays an important role in fattening. It is well eaten by small cattle in late autumn and winter. Especially in snow-frosted flowers, when ephemerals are covered with snow, they are eaten in sufficient quantity $[6,10]$.

In general, due to the inefficient use of xerophytes, which are important forage crops in the semi-desert vegetation of the Caspian coast, the process of degradation or degradation of soil and vegetation is accelerated, valuable forage crops are destroyed, and productivity is reduced; the abundance of harmful and poisonous plants is increasing. Therefore, it is recommended to take measures for the proper (efficient) use and improvement of the studied semi-desert vegetation $[3,6,10,7]$.

\section{REFERENCE}

1. Dictionary of Azerbaijan Flora / V. C. Hajiyev and B. E. n. By T.E. Gasimovan. Baku: Science; 2008. 272 p.

2. Research on Biodiversity of the Republic of Azerbaijan (First National Report on the Convention on Biological Diversity). Baku, ANAS "Alfarul"; 2004. $160 \mathrm{p}$.

3. Instruction on large-scale geobotanical researches of natural forage areas of the Republic of Azerbaijan. Baku: Maarif; 2002. $142 \mathrm{p}$.

4. Axundova A. A. Bioecology, protection and restoration of vegetation of Absheron peninsula. Boil. Ph.D. Autoref. Baku; 2012. 23 p.

5. Askerov A. M. Flora of Azerbaijan (Higher plants - Embriophyta). Baku: Teass-Press Publishing House; 2016. 444 p.

6. Hatamov V. V. Pasture ecosystems and protection of Azerbaijan. Baku: Science; 2000. 184 p.

7. Hüseynova H. Z. Ecological features of flora and vegetation of Samur-Shabran lowland. Boil. Ph.D. Autoref. Baku; 2014. 23 p.

8. Qurbanov E. M., Cabbarov M. T. Geobotany. Baku: Baku State University publishing house; 2017. 320 p.

9. Novruzov V. S., Gurbanov E. M., Ismayilova Z. M. Plant ecology (with the basics of geo-botany). Baku: Baku State University publishing house; $1998.197 \mathrm{p}$.

10. Agaguliev I. M. Flora and vegetation of South-Eastern Shirvani. Baku: Baku University Press; 2000. 147 p.

11. Bykov B. A. Ecological dictionary. Nauka Publishing House of the Kazakh SSR. Alma-Ata; 1988, 245 p.

12. Flora of Azerbaijan. Baku: Izd-vo AN Azerbaijan. SSR; 1950-1961. T. I-8.

13. Shennikov A. P. Introduction to geobotany. .: LGU Publishing House; $1964.447 \mathrm{p}$.

14. Ecology and nature use. On the methodology of the program of ecological research of the Academy of Sciences of the USSR / Pod. ed. G. V. Dobrovolsky et al. Chisinau,;1989. 44 p.

15. Yaroshenko P. D. Geobotany. M.: Enlightenment; 1969.200 p.

16. Cerepanov S. K. Vascular Plomts of Rusia and Agrosent States the forner USSR. North American Branch. Cambridge University Press; 1995.992 p.

\section{СПИСОК ЛИТЕРАТУРЫ}

1. Словарь флоры Азербайджана / В.С. Гаджиев и Б. Е. н. Т. Е. Гасимова. Баку: Наука, 2008. 272 с.

2. Исследование биоразнообразия Азербайджанской Республики (Первый национальный доклад по Конвенции о биологическом разнообразии). Баку: НАНА «Альфарул», 2004. 160 с.

3. Инструкция по крупномасштабным геоботаническим исследованиям природных кормовых угодий Азербайджанской Республики. Баку: Маариф, 2002. 142 с.

4. Ахундова А. А. Биоэкология, защита и восстановление растительности Апшеронского полуострова: автореф. дис.... канд. пед. наук. Баку, 2012. 23 с.

5. Аскеров А. М. Флора Азербайджана (высшие растения - эмбриофиты). Баку: Тисс-Пресс, 2016., 444 с.

6. Хатамов В. В. Пастбищные экосистемы и охрана Азербайджана. Баку: Наука, 2000, 184 с.

7. Хусейнова Х. З. Экологические особенности флоры и растительности Самур-Шабранской низменности: автореф. дис. ... канд. пед. наук. Баку, 2014. 23 стр.

8. Гурбанов Е. М., Каббаров М. Т. Геоботаника. Баку: Изд-во Бакин. гос. ун-та, 2017. 320 с.

9. Новрузов В. С., Гурбанов Е. М., Исмаилова 3. М. Экология растений (с основами геоботаники). Баку: Изд-во Бакин. гос. ун-та, 1998. 197 с.

10. Агагулиев И. М. Флора и растительность Юго-Восточного Ширвани. Баку: Изд-во Бакин. гос. у-та, 2000. 147 с.

11. Быков Б. А. Экологический словарь. Алма-Ата: Наука,1988, 245 с.

12. Флора Азербайджана. Баку: Изд-во АН Азербайджанской ССР, 1950-1961. Т. I-8.

13. Шенников А. П. Введение в геоботанику. Л.: Изд-во ЛГУ, 1964. 447 с.

14. Экология и природопользование. О методологии программы экологических исследований Академии наук СССР / под ред. Г. В. Добровольского [и др.]. Кишинев, 1989. 44 с.

15. Ярошенко П. Д. Геоботаника. М.: Просвещение, 1969. 200 с.

16. Черепанов С. К. Сосудистые пломбы России и Агросентных государств бывшего СССР. Североамериканское отделение. Кембриджский университет: Пресса, 1995. 992 с. 